\title{
Ultrafiltrate of saliva collected in situ for the measurement of testosterone
}

\author{
Willfried Schramm * \\ Unversity of Michigan, Reproductue Sciences Program and Bioengineering Program, $300 \mathrm{~N}$ Ingalls, Ann Arbor, MI 48709, \\ and ${ }^{*}$ BioQuant, 1919 Green Rd, Ann Arbor, MI 48103 (USA)
}

\section{Se-Hwan Paek, Ha1-Hang Kuo and Tony Yang}

University of Michigan. Reproductwe Sciences Program and Bloengineering Program, 300 N Ingalls, Ann Arhor, MI 48709 (USA)

(Received 1st November 1990)

\begin{abstract}
A device for the in situ collection of an ultrafiltrate of saliva was investigated The collector consists of an osmotic pump that, when placed in the mouth, accumulates a prepurified salivary filtrate within a few munutes The concentration of testosterone in saliva and in the ultrafiltrate from five male subjects was determined by a solid-phase immunoassay The ultrafiltrate can be used without extraction as a medium for the diagnostic evaluation of free, protein-unbound testosterone. Concentrations in whole salıva and the ultrafiltrate correlate closely $(r=089, n=42)$ The collector can potentially be used for the measurement of a wide variety of analytes other than testosterone An ultrafiltrate of saliva as diagnostıc medium provides the following advantages simplicity of collection; moderate stımulation of salivary flow, exclusion of potential blood contamination, prevention of binding of analytes to proteins; prevention of potential metabolic degradation of analytes, reduction of viscosity by exclusion of mucopolysaccharides and other large molecules, and potential sterile samplıng of ultrafiltrate
\end{abstract}

Keywords Immunoassay; Osmotic pump; Saliva, Testosterone

For many years, saliva has been considered as an alternative biological medium for the diagnostic evaluation of patients. As it can be collected non-invasively, new opportunities arıse for studying the secretion of biological markers or the effects of drug treatment. Samples can be collected at frequent intervals; from patients for whom venipuncture is or has become difficult; at any location, including at home; and in studies where phlebotomy is not advisable (e.g., cross-sectional studies of school children, monitoring of native populations). Although salıva cannot be considered as a substitute for blood in diagnostic evaluations per se, for many applications it is equal or even superior to serum or plasma for the determination of physiologically active substances.

Despite the many advantages saliva offers for a number of diagnostic evaluations, it also has certain limitations. A simple method has becn developed to collect an ultrafiltrate of saliva in situ to overcome several of the existing limitations and to improve the utility of salıva as a biological medium The ultrafiltrate is collected by means of a small pouch, constructed of a sempermeable membrane and enclosing an osmotically active substance, which is put into the patient's mouth. The pouch fills up within a few minutes with a clear filtrate of saliva. 
For the studies presented in this paper, the steroid hormone testosterone was selected to investigate the correlation between the concentrations in conventionally collected whole saliva and an ultrafiltrate thereof. Over the last 8 years, more than 90 papers have been published on the investigation of testosterone in saliva. Most of the authors recommend the measurement of salivary testosterone as the superior method of determıning the free circulating steroid concentration.

Salivary testosterone has been used for the assessment of a wide variety of different physiolog1cal states. Without attempting to provide a complete list, these studics include the: detcrmination of gonadal function in boys [1] and men [2-4], monitoring after treatment of prostatic carcinoma $[5,6]$, evaluation of sexual [7] and aggressive behavior [8] including prison inmates [9], studies on hirsute [10,11] and transsexual women [12], stress in marathon runners [13] and other subjects [14], sex role and identity in females [15] and Klinefelter's syndrome [16].

Testosterone is bound in circulating blood to sex hormone-binding globulin (SHBG) and, with a lower affinity, to albumin. As the concentration of SHBG can vary widely, and as only the free, unbound portion is considered to be physiologically active, measurement of free testosterone is of great diagnostic value. It is cumbersome and relatively expensive to measure free biological markers and drugs in blood by separating the free fraction from the bound (e.g., by ultrafiltration). Although immunoassays have been developed for the direct detection of free testosterone in serum and plasma, these assays are not available for the majority of other molecules that are likewise circulating as a bound and a free fraction. For many substances, saliva offers a medium where the free component is naturally separated from the bound portion.

The measurement of progesterone in an ultrafiltrate of saliva during the menstrual cycle of women has been reported previously [17]. The objective of this study was to develop different methods for optimum collection with the osmotic pump, to demonstrate the validity of using an ultrafiltrate of saliva collected in situ from normal, healthy male subjects for the determination of testosterone and to correlate the concentrations with those found in regularly collected whole saliva free from obvious blood contammation or gingival fluid.

\section{EXPERIMENTAL}

\section{Reagents}

Tyrosine methyl ester, chloramine T, $\alpha$-amylase (type VI-A from porcine pancreas), sucrose, fructose and citric acid were purchased from Sigma (St. Louis, MO) and dicyclohexylcarbodiimide, chloroform and acetonitrile from Aldrich (Milwaukee, WI).

Phosphate buffers consisted of sodium phos-

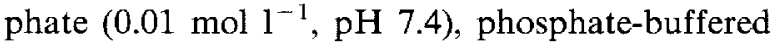
saline (PBS) contained $9 \mathrm{~g} \mathrm{NaCl}$ per liter of phosphate buffer and gel-PBS consisted of PBS containing gelatın $\left(1 \mathrm{~g} \mathrm{l}^{-1}\right)$.

\section{Samples}

Saliva was collected from five healthy male volunteers who were not on any medication The subjects did not brush their teeth for at least $2 \mathrm{~h}$ before collection and in the same period they did not consume any hard food or candy that could potentially lead to lacerations of the oral mucosa or the gums. None of the volunteers had gingivitis or periodontitis. For all the collected samples, no obvious contamination of collected saliva with traces of blood was observed.

For the collection of whole saliva, the subjects did not swallow or expel liquid for about $5 \mathrm{~min}$ but accumulated secreted saliva over this period of time and then expelled it into a $30-\mathrm{ml}$ propylene container. This procedure stımulates salivary flow and, typically, 4-5 $\mathrm{ml}$ with little froth are obtained.

Immediately after collecting whole saliva, the volunteers placed the collector in their mouth, collecting an ultrafiltrate over a period of $10 \mathrm{~min}$. Prior to collection, the collector was immersed in tap water for $10 \mathrm{~s}$. The collector was frequently moved around in the mouth so that saliva could easily access the whole surface area of the device. The filled collector was stored in the same type of polypropylene containers as mentioned above, and 
the containers were tightly closed with screw-caps for storage.

For the determination of diurnal variations, samples were collected from one volunteer at different times and on different days. For these collections, the subject did not sleep for at least $1 \mathrm{~h}$ before collection and was in an upright position.

All samples were stored frozen until analyzed. Salıva was centrifuged prior to assaying; the ultrafiltrate was used without centrifugation The density of the ultrafiltrate was measured by weighing $1 \mathrm{ml}$ of liquid on an analytical balance.

Preparation and radiolabeling of testosterone$11 \alpha$-hemusuccinyl tyrosine methyl ester

Testosterone-11 $\alpha$-hemisuccinyl tyrosine methyl ester (T-TME) was synthesized by acylation of 4-androstene-11 $\alpha, 17 \beta$-diol-3-one 11-hemisuccinate (Steraloids, Wilton, NH) with tyrosıne methyl ester in dioxane using dicyclohexylcarbodimide for activation of the steroid. The product was isolated by extraction into chloroform; the chloroform was removed by evaporation with nitrogen and the residue was purified by liquid chromatography (LC). T-TME was stored at $-20^{\circ} \mathrm{C}$ in acetonitrile.

T-TME (700 ng) was iodinated by incubation with $2 \mathrm{mCl}$ of $\mathrm{Na}^{125} \mathrm{I}\left(2175 \mathrm{Ci} \mathrm{mmol}{ }^{-1}\right)$ and chloramine $\mathrm{T}(20 \mu \mathrm{g})$ in $0.05 \mathrm{ml}$ of $\mathrm{NaHKPO}_{4}(0.5$ mol $1^{-1}, \mathrm{pH} \mathrm{7.4)}$ for $1 \mathrm{~min}$. The reaction was stopped with $20 \mu \mathrm{g}$ of sodium metabisulfite after 1 min [18]. The monoiodinated product was separated from unreacted ${ }^{125} I$ and the diiodinated compound by means of a dual-pump LC system (Beckman Instruments, San Ramon, CA) equipped with an Ultrasphere IP column $(250 \mathrm{~mm} \times 4.6$ $\mathrm{mm}$ i.d.), $5 \mu \mathrm{m}$ particle size (Beckman Instruments), which was pre-equilibrated with acetonitrile-potassium formate buffer $\left(50 \mathrm{mmol} \mathrm{l}^{-1}, \mathrm{pH}\right.$ 4.0) $(20+80, v / v)$ at ambient temperature. Derivatives were separated by elution with a linear gradient of increasing acetonitrile concentration (increasing by $1 \%$ acetonitrile $\mathrm{min}^{-1}$ for $60 \mathrm{~min}$ ). Elution of the labeled compounds was detected with a Beckman Model 170 radioisotope detector and radioactive fractions were automatically collected with a Gilson Model FC203 fraction collector (Gilson Medical Electronics, Middleton, WI).
Only the fraction containing the monoiodinated $\left[{ }^{125}\right.$ I]T-TME was used for the immunoassays. This fraction was neutralized with $0.2 \mathrm{ml}$ of $\mathrm{NaKHPO}_{4}$

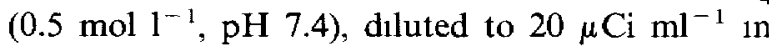
absolute ethanol, and stored at $4^{\circ} \mathrm{C}$. For solidphase assays, working solutions were prepared by diluting the ethanol solution to about $3 \times 10^{5}$ counts $\mathrm{min}^{-1}$ in $1 \mathrm{ml}$ of gel-PBS.

\section{Collector}

Tubular dialysis membrane (Cuprophan; Enka, Germany) of $45 \mathrm{~mm}$ flat width and $20 \mu \mathrm{m}$ thickness was cut into $30-\mathrm{mm}$ segments, filled with $2 \mathrm{~g}$ of sucrose and the ends were tied with braided nylon surgical suture (No. 3; Deknatel, Queens Village, NY). The filled collector had a spherical shape of about $20 \mathrm{~mm}$ diameter. Other collectors used in this study were filled with $2 \mathrm{~g}$ of sucrose containing $60 \mathrm{mg}$ of citric acid, with $2 \mathrm{~g}$ of fructose or with $1 \mathrm{~g}$ of sucrose. The molecular weight cut-off of the semipermeable membrane is ca. 12000 dalton.

Ultrafiltrate obtained with the collector contains a certain amount of carbohydrate. The density of $1 \mathrm{ml}$ of the filtrate was measured. The amount of water per unit volume, $C_{w}$, was determined [19]. A correction factor, $f=1 / C_{\mathrm{w}}$, was derived by which the concentration of testosterone in the ultrafiltrate was multiplied.

The osmolality of sucrose and fructose was measured at a concentration of $100 \mathrm{~g}^{-1}$ against calibrators made from sodium chloride with an Osmometer (Model LAS; Advanced Instruments, Newton Highlands, MA).

\section{Transfer of testosterone}

A pool of saliva collected from women was spiked with 50 and $150 \mathrm{pg} \mathrm{ml}^{-1}$ of testosterone. A volume of $10 \mathrm{ml}$ of the pre-warmed $\left(37^{\circ} \mathrm{C}\right)$ spiked saliva was enclosed together with a collector in a zuplock polyethylene plastic bag, submerged in a water-bath at $37^{\circ} \mathrm{C}$ and the bag was gently massaged for predetermined periods of time to simulate the exposure of the collector in the mouth while moved around with the tongue. The testosterone concentrations outside and inside the collector were measured for the determination of 
transfer at different time intervals. For each time point, four separate transfer experiments were performed.

\section{Non-spectfic binding}

Iodinated derivatives of seven molecules from different substance classes (dehydroepyandrosterone, estradiol, progesterone, testosterone, benzoylecgonine, thromboxane $B_{2}$ and phenytoin) were incubated in the presence of excess nonlabeled analyte ( $>6$-fold) in $10 \mathrm{ml}$ of phosphate buffer solution containing $1 \mathrm{~g}^{-1}$ gelatin with three pieces of $100 \mathrm{~mm}^{2}$ of the semipermeable membrane for $60 \mathrm{~min}$. The membrane was removed and agitated for $5 \mathrm{~s}$ in $200 \mathrm{ml}$ of deionızed water to remove external traces of liquid containing radiolabeled derivative Thereafter, the remaining radioactivity on the membrane was determined by monitoring the $\gamma$-irradiation.

\section{Immobilization of antubody}

A rabbit antıbody to testosterone (Cambndge Medical Technology, Billerica MA) was immobilized to strips of twelve break-apart 1.4-ml Macrowells (Skatron, Sterling, VA). The microwells were filled with $200 \mu 1$ of a solution of $1 \mathrm{mg}^{-1}$ of polylysine in carbonate buffer $\left(0.05 \mathrm{~mol}^{-1}\right.$ sodium carbonate, $\mathrm{pH}$ 9.6) and incubated overnight at room temperature in a closed container. The macrowells were emptied and washed three times with $500 \mu 1$ of deionized water; a solution containing the antibody (1:5000 dilution) and 0.3 mmol $1^{-1}$ of sodium periodate in phosphate buffer $\left(0.05 \mathrm{~mol} \mathrm{l}^{-1}\right.$ of phosphate, $\left.\mathrm{pH} 7.4\right)$ in a volume of $200 \mu 1$ was distributed into the polylysine treated wells, and incubated at $4^{\circ} \mathrm{C}$ in closed containers in the dark for $24 \mathrm{~h}$. Thereafter, the incubation solution was discarded, the wells were washed three times with $500 \mu \mathrm{l}$ of deionızed water, air dried and stored at $4^{\circ} \mathrm{C}$ in a closed container with silica gel as desiccant.

\section{Assay procedure}

Arrange the macrowells with immobilized antibody in an $8 \times 12$ array in carriers provided for the system (Skatron). Add to the wells $400 \mu \mathrm{l}$ of saliva or the ultrafiltrate, $600 \mu 1$ of gel-PBS and
$200 \mu 1$ of ${ }^{125}$ I-labeled T-TME $(25000$ counts $\min ^{-1}$; ca. $8 \mathrm{pg}$ ). Cover the wells with plastic film (Saran wrap), attach to a rotisserie and rotate at slow speed for $60 \mathrm{~min}$. Pour off liquid, wash three t1mes with $500 \mu 1$ of deionized water and count the radioactivity bound to the wells in a gamma counter (Searle 1285, TM Analytic, Elk Grove Village, MI).

Investigate the effect of sucrose at different concentrations $\left(0.3,0.6\right.$ and $\left.0.9 \mathrm{~mol}^{-1}\right)$ and of sucrose $\left(0.3 \mathrm{~mol} \mathrm{1}^{-1}\right)$ containing citric acid (31 mmol $1^{-1}$ ) on the immunoassay.

Determine the accuracy of the assay, by extracting a pool of ultrafiltrate of saliva with charcoal (500 $\mathrm{mg} \mathrm{ml}^{-1}$ ) under gentle agitation on an orbital shaker for $2 \mathrm{~h}$ and remove the charcoal by ultracentrifugation Add to this preparation, 50, 100 and $200 \mathrm{pg} \mathrm{ml}^{-1}$ of testosterone and determine the recovery.

\section{RESULTS}

\section{Immunoassay}

Assay characteristics. The average inflection point of a typical dose-response curve for the testosterone assay at $50 \%$ inhibition of radiolabeled tracer by testosterone is $77 \mathrm{pg}$ per well (twelve assays). The intra-assay relative standard deviation (R.S.D.) was $8.5 \%$ for single determinations at 70 pg per well and the inter-assay R.S.D. at the same concentration was $11.2 \%$.

Saliva samples and the ultrafiltrate were assayed directly without extraction. The high viscos1ty of saliva made it necessary to agitate the incubation mixture, which was satisfactorily achieved by slow rotation of the macrowells on a rotisserie. The remaining air bubbles in the wells contributed to thorough mixing by continuously invertıng the wells during the period of incubation. As the antibody was bound at an area of the wells that was covered by $200 \mu \mathrm{l}$ of medium, the sodium iodide crystal of the $\gamma$-counter could capture the radiation without geometric limitations.

Detection limit For displacing 5\% of the radiolabeled tracer, a mean concentration of $242 \mathrm{pg}$ per well $(\mathrm{S} . \mathrm{D} .=0.88 \mathrm{pg}$ per well) was required (average of twelve consecutive assays). 
TABLE 1

Accuracy of the sold-phase assay for testosterone

\begin{tabular}{rclc}
\hline $\begin{array}{l}\text { Testosterone } \\
\text { added } \\
\left(\mathrm{pg} \mathrm{ml}^{-1}\right)\end{array}$ & $\begin{array}{l}\text { Testosterone } \\
\text { recovered } \\
\left(\mathrm{pg} \mathrm{ml}^{-1}\right)\end{array}$ & $\begin{array}{l}\text { S D } \\
\left.(\mathrm{pg} \mathrm{ml})^{-1}\right)\end{array}$ & Recovery (\%) \\
\hline 50 & 465 & 5.5 & 93 \\
100 & 975 & 8.5 & 98 \\
200 & 2086 & 4.3 & 104 \\
\hline
\end{tabular}

Accuracy The recoveries of testosterone added at three different concentrations to ultrafiltrate samples from saliva that were stripped with charcoal are shown in Table 1. The results are averages of three determinations.

Parallelism. $\Lambda$ sample of ultrafiltrate was assayed undiluted and in three different dilutions. The observed and expected values are presented in Table 2 ( $n=5$ per dilution). The results show that the analytical methods maintains good linearity on dilution.

Effect of sucrose The collected ultrafiltrate contains a high concentration of sucrose. Although the sample was diluted with assay buffer, $400 \mu 1$ of ultrafiltrate as used in the assays contains a substantial amount of carbohydrate that could potentially interfere with the immunoassay. Therefore, the effect of different concentrations of sucrose on the immunoassay was investigated. Typically, the final concentration of sucrose in the ultrafiltrate ranged between 0.3 and $0.6 \mathrm{~mol}^{-1}$ Concentrations as high as $0.9 \mathrm{~mol}^{-1}$ did not have a significant effect on the immunoassay (Table 3)

\section{Collector}

Osmotically active substance The accumulation of liquid in the collector was investigated with sucrose and fructose as osmotically active sub-

\section{TABLE 2}

Parallelism of analyte detection in $\mathrm{pg} \mathrm{m}^{-1}$ after dilution of a sample

\begin{tabular}{lccc}
\hline Dilution & Expected $(E)$ & Measured $(M)$ & $E / M(\%)$ \\
\hline Undiluted & - & 128 & - \\
12 & 63.9 & 718 & 112 \\
13 & 421 & 456 & 107 \\
14 & 320 & 272 & 85 \\
\hline
\end{tabular}

TABLE 3

Testosterone recovered in samples containing different amounts of sucrose after adding a known amount of the sterold

\begin{tabular}{lrrrr}
\hline $\begin{array}{l}\text { Testosterone } \\
\text { added } \\
\left(\mathrm{pg} \mathrm{ml}{ }^{-1}\right)\end{array}$ & \multicolumn{4}{c}{ Testosterone recovered $\left(\mathrm{pg} \mathrm{ml}^{-1}\right)$} \\
\cline { 2 - 5 } & $00^{\mathrm{a}}$ & $03^{\mathrm{a}}$ & $06^{\mathrm{a}}$ & $09^{\mathrm{a}}$ \\
\hline 50 & 47 & 52 & 45 & 48 \\
100 & 93 & 88 & 97 & 86 \\
200 & 192 & 187 & 185 & 182 \\
300 & 280 & 277 & 286 & 288 \\
\hline
\end{tabular}

${ }^{2}$ Testosterone assayed in the presence of $00,0.3,06$ and 0.9 mol $1^{-1}$ sucrose

stances. Although the osmolality of the monosaccharide fructose was almost twice as high (540 mOsm kg-1 of water) as that of the disaccharide sucrose ( $290 \mathrm{mOsm} \mathrm{kg}{ }^{-1}$ ) for the same concentration of sugar $\left(100 \mathrm{mg} \mathrm{ml}^{-1}\right.$ ), the accumulated volume in the collector did not differ significantly over time (Fig. 1). Faster migration of the smaller molecule (fructose) out of the device during the collection process might counteract the higher osmolality.

The density of the ultrafiltrate decreases with increasing volume in the collector (Fig. 2). If the device contains $2 \mathrm{~g}$ of sucrose, it becomes turgid after about $15 \mathrm{~min}$ in the mouth and the increasing internal pressure starts to work against the osmotic pressure. Over a period of $15 \mathrm{~min}$, about 5 $\mathrm{ml}$ of a clear ultrafiltrate can be collected.

Volume and density. Collectors containing only $1 \mathrm{~g}$ of sucrose fill more slowly and the change in

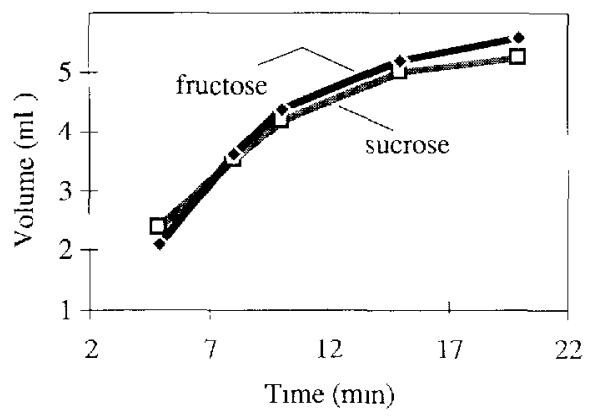

Fig 1 Volume of ultrafiltrate of saliva accumulated with time in the collector does not differ significantly if the same mass ( 2 $g$ per collector) of the monosaccharide fructose or the d1saccharide sucrose is used as an osmotically active substance 


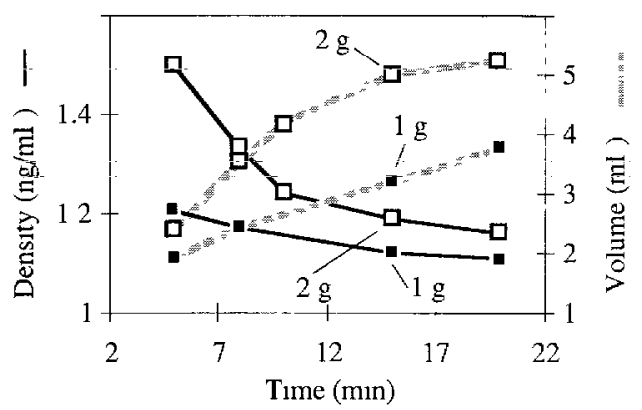

Fig. 2 Density and volume of the ultrafiltrate obtained with the collector as a function of time. Data are shown for collectors containing 1 and $2 \mathrm{~g}$ of sucrose

density over time of the ultrafiltrate is smaller (Fig. 2). About $3 \mathrm{ml}$ of ultrafiltrate accumulated over a collection time of $15 \mathrm{~min}$. These collectors did not fill to capacity and were flaccid even if they remained in the mouth as long as $30 \mathrm{~min}$.

If the collector is put into the mouth, the membrane hydrates untll aqueous medium penetrates the entire thickness of the membrane and the carbohydrate crystals start to dissolve. During this phase, until the membrane is completely wet, the collector may stick to the roof of the mouth and can be moved around by the tongue only with some difficulty. The membrane can be hydrated by immersing the collector in water for a few seconds prior to use, a method routinely used in this investigation. Once the collector is wet, moving it around in the mouth moderately stimulates salivary flow.

Effect of citric acld. Citric acid is a very potent stimulant for salivary secretion. Therefore, collectors containing sucrose and $3 \%(\mathrm{w} / \mathrm{w})$ citric acid were investigated. The volume collected within a certain period of time did not differ when the collector contained citric acid, but some subjects reported the initial stimulation of saliva flow as beneficial.

The $\mathrm{pH}$ of the ultrafiltrate is acidic and the acidity decreases with increasing time of collection (Fig. 3). Assuming that the citric acid permeates the membrane of the collector in a similar fashion to sucrose, the amount remaining in the ultrafiltrate after $15 \mathrm{~min}$ of collection ( $31 \mathrm{mmol}^{-1}$ ) was calculated and the effect on the immunoassay was determined.

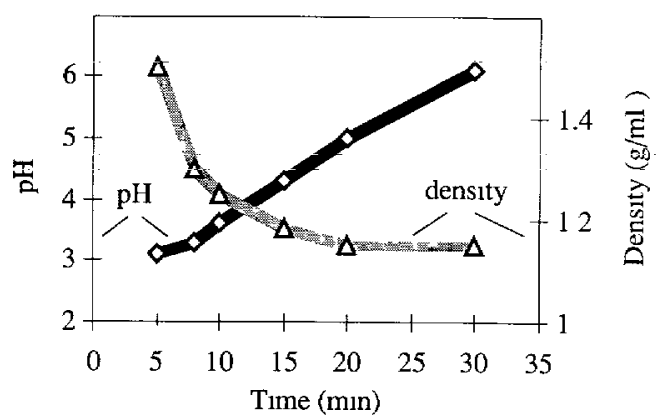

Fig 3 Acidity of the ultrafiltrate containing $3 \%$ citric acid as a stımulant for salıvation at different collection tımes

As $400 \mu 1$ of the ultrafiltrate were used in a total volume of $1.2 \mathrm{ml}$ in the immunoassay, the buffer capacity was not sufficient to maintain a $\mathrm{pH}$ of 7.4. Under these conditions, inaccurate high readings were obtained if assessed against standards made up in assay buffer (Table 4, top two entries). This effect could be overcome if the phosphate concentration in the buffer was increased 10-fold (to $0.1 \mathrm{~mol} \mathrm{l}^{-1}$; Table 4, bottom two entries).

Transfer of testosterone. The concentration of testosterone in the ultrafiltrate relative to the concentration in saliva surrounding the collector (recovery) does not change significantly as a function either of time or of the accumulated volume in the collector. Increasing the concentration from 50 to $150 \mathrm{pg} \mathrm{ml}^{-1}$ of testosterone in saliva did not have an effect on the transfer of the steroid (Fig. 4; average transfer for $50 \mathrm{pg} \mathrm{ml} l^{-1}=85.4 \%$ and for $150 \mathrm{pg} \mathrm{ml}^{-1}=84.8 \%$ ).

The transfer of testosterone in phosphate buffer

TABLE 4

Apparent concentration of testosterone in the presence and absence of citrate ( $31 \mathrm{mmol}^{-1}$ ) If assayed in buffer containing different concentrations of phosphate buffer

\begin{tabular}{ll}
\hline Buffer solution & $\begin{array}{l}\text { Testosterone } \\
\text { concentration } \\
\left(\mathrm{pg} \mathrm{ml}^{-1}\right)\end{array}$ \\
\hline $001 \mathrm{~mol} \mathrm{l}^{-1}$ phosphate, no citrate & 417 \\
$001 \mathrm{~mol} \mathrm{l}^{-1}$ phosphate + citrate & 712 \\
$01 \mathrm{~mol} \mathrm{l}^{-1}$ phosphate, no citrate & 425 \\
$01 \mathrm{~mol}^{-1}$ phosphate+ citrate & 435 \\
\hline
\end{tabular}




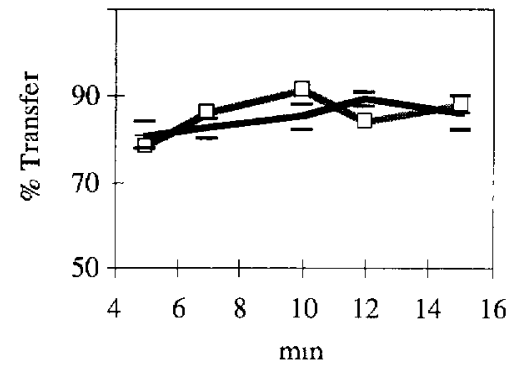

Fig 4. Transfer of testosterone (gray line $50 \mathrm{pg} \mathrm{ml}^{-1}$, black line $150 \mathrm{pg} \mathrm{ml}^{-1}$, standard deviations for four expenments are shown) into the osmolic device expressed as a percentage of the concentration in the ultrafiltrate vs. the concentration in external saliva measured at different tıme intervals.

containing $1 \%$ of gelatin was very similar to that with saliva (results not shown).

Non-specific binding. Analytes of different molecular structure bind to the cellulose membrane of the device in the lower picogram range. Binding can vary substantially and, even within a specific substance class (e.g., steroids, Table 5), a 10-fold difference in non-specific binding was obscrved.

Correlation of testosterone in saliva and ultrafiltrate

The concentration of testosterone in saliva samples from volunteers correlated closely with the concentration in the ultrafiltrate collected at the same time (Fig. 5). On average, about $85 \%$ of the concentration in saliva was measured in the ultrafiltrate. This is very simılar to the recovery found in the in vitro experiments (Fig. 4). Part of the negative intercept of the regression equation (Fig. 5) may be accounted for by non-specific binding to the device (see Table 5).

\section{TABLE 5}

Non-specifıc bindıng of different analytes to the collector

\begin{tabular}{lcll}
\hline Analyte & $\begin{array}{l}\text { Binding } \\
\text { (pg per } \\
\text { device) }\end{array}$ & Analyte & $\begin{array}{l}\text { Binding } \\
\text { (pg per } \\
\text { device) }\end{array}$ \\
\hline Dehydroep1- & & Testosterone & 18 \\
$\quad$ androsterone & 165 & Benzoylecgonine & 17 \\
17ß-Estradiol & 63 & Thromboxane $B_{2}$ & 19 \\
Progesterone & 31 & Phenytom & 0.3 \\
\hline
\end{tabular}

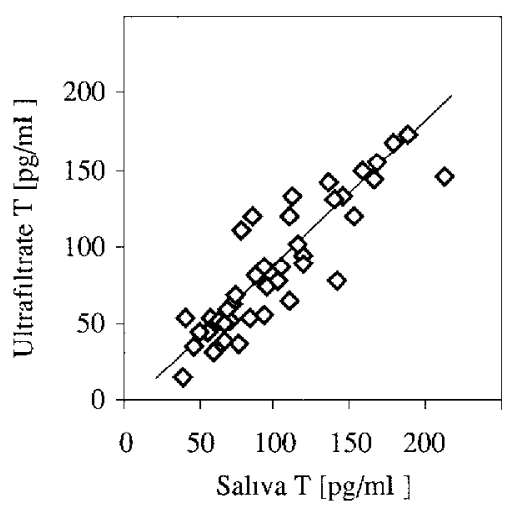

F1g. 5. Measurement of testosterone in 42 matching saliva samples (saliva $T$, abscissa) and samples collected with the osmotic device (ultrafiltrate $\mathrm{T}$, ordinate) The regression equation is $y=-3.20+087 x ; r=089$.

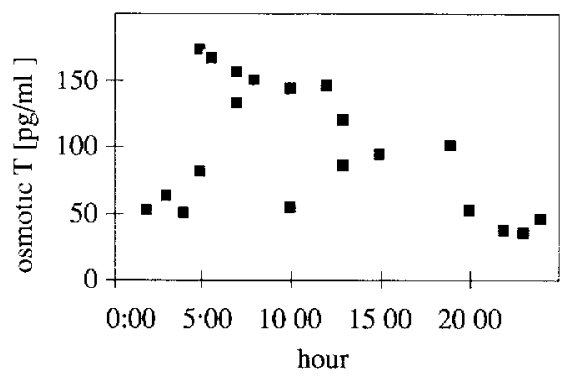

Fig. 6. Testosterone concentration in the ultrafiltrate correlates with the time of collection (diurnal thythm) The samples were collected on different days from one individual.

The concentrations were close to the range that other workers have reported for testosterone in saliva (30-200 $\mathrm{pg} \mathrm{ml}^{-1}$ [20]; 78-251 $\mathrm{pg} \mathrm{ml}^{-1}$ [21]; $100-280 \mathrm{pg} \mathrm{ml}^{-1}$ [22]; 90-130 $\mathrm{pg} \mathrm{ml}^{-1}$ [23]; 30$\left.240 \mathrm{pg} \mathrm{ml}^{-1}[24]\right)$.

\section{Diurnal variation of testosterone}

The testosterone concentrations in the ultrafiltrate samples from one volunteer were plotted against the time of collection (Fig. 6). Although there was variation in the concentration at defined times, a circadian rhythm is clearly present.

\section{DISCUSSION}

The classical method for the separation of free from protein-bound molecules through a semiper- 
meable membrane is equilibrium dialysis [25]. The method has been applied for plasma and for saliva as medium [23]. With the described collector, one can achieve the same results much more conven1ently, at lower cost, in a shorter period of time and in situ while the patient collects the sample.

The "normal range" of testosterone in saliva from males has been controversial for some time and wide variations have been reported [26]. Assay technology and preparation of the samples may contribute to this variation, as may different concentrations of proteins in saliva. With the collector, proteins are excluded completely and as early as possible, i.e., directly in the mouth.

Withın the physiological range of concentrations, transfer of testosterone through the semipermeable membrane is a process that is not dependent on the amount of the sterord in the external fluid (Fig. 4). After saturating the comparatively small number of non-specific binding sites on the membrane surface (Table 5), the ultrafiltrate entering the osmotic device carries an almost constant ratio of testosterone from the external liquid through the membrane, independent of the accumulated volume in the device.

The concentration of testosterone in saliva exceeds that found in the ultrafiltrate. No difference was found in the in vitro model between the recovery of testosterone from saliva and from phosphate buffer containing $1 \mathrm{~g} \mathrm{l}^{-1}$ gelatin, despite the diverse salivary content of glycoproteins, mucins and protein components from microorganisms. Therefore, it is concluded that the lower, but concentration-independent and constant with time, transfer is caused by the physical properties of the semipermeable membrane rather than the composition of the medium. It is possible that this is a reflection of the faster permeation rate of the water molecules compared with the steroid molecules. This hypothesis will be tested with other analytes in future experuments.

An attempt was made to collect for this study saliva samples that do not have excessive amounts of gingival fluid or blood protein contaminants Saliva contains bindıng globulin and albumin [27]. The source of these proteins can be either gingival fluid that may constitute up to $0.5 \%$ of the volume of salıva in healthy subjects [28] or blood compo- nents which are found in the saliva of $20-50 \%$ of the normal population $[29,30]$. The semipermeable membrane of the collector excludes the binding globulins, and the concentration in the ultrafiltrate reflects the truly free component of the steroid in saliva. Therefore, the use of the collector has particular advantages for the determination of the free circulating fraction of testosterone and other highly protein-bound molecules in patients with gingivitis, periodontitis, lacerations of the oral mucosa after dental treatments, and for children who have lost a tooth. A study has now been unitiated to investigate systematically the effect of clcvated gingival fluid and blood protcins on the testosterone concentration found in whole saliva compared with the ultrafiltrate collected with the osmotic device.

The diurnal alteration of testosterone concentrations in saliva from males has becn well documented [21,24,31,32]. Changes within an individual can vary widely and have been reported to be as high as $220 \mathrm{pg} \mathrm{ml}^{-1}$ between 8:00 and 9:00h and to fall to $72 \mathrm{pg} \mathrm{ml}^{-1}$ between $22: 00$ and 23:00h [24]. On the other hand, some individuals show little or no diurnal rhythm. In most of these studies, the potential interference of steroid binding proteins as a source of variation has not been eliminated. The collector provides a means for simplified collection of proten-free samples. Preliminary studies using the ultrafiltrate of saliva for the estimation of progesterone concentration over time are shown in Fig. 6 . The samples were not collected on the same day. This might be the reason for the observed variations of testosterone concentrations in samples collected at the same time on different days. Although the diurnal variation was investigated in only one individual, a clear trend of changing testosterone concentrations over time that is supported by earlier findings has been shown.

It has been suggested that the decrease in testosterone level in the morning might be related to increased salivary flow upon waking [31]. However, salivary cortısol and aldosterone concentrations are not greatly influenced at flow-rates above a minimum but are higher at low flow rates $[33,34]$. As the samples shown in Fig. 6 were taken during waking, and as the collector slightly stimulates 
salivary flow, it is not likely that the diurnal variation is related to flow-rate.

The collector used to obtain a pre-processed sample of saliva is an osmotic pump. Both sucrose and fructose were investigated as osmotically active substances, although other non-toxic substances can be used. It was surprising that with the monosaccharide fructose the collector did not fill faster than with the disaccharide sucrose that has about half the molecular mass. It appears that the osmotic action is superimposed upon another effect if the collector is used in the mouth. Because the user is instructed to move the collector around in the buccal cavity, the device is exposed to a constant massaging action. The semipermeable membrane can be envisioned as a sponge. This sponge contracts and expands as a result of the action of the tongue, thereby accelerating the transfer of substances. The higher osmotic pressure inside the collector causes the transfer to be one-directional.

It was decided to carry out the correlation studies with sucrose because fructose is hygroscopic and collectors would have to be stored desiccated over extended periods of time. We did not observe any interference of sucrose in the immunoassay, even at comparatively high concentrations. The volume of the ultrafiltrate collected within $10 \mathrm{~min}$ is sufficient for many applcations. Should a larger volume be required for some analytical methods, collection with two devices either simultaneously or consecutively is feasible. Another alternative is to collect over longer periods of time.

The high concentration of sucrose in the ultrafiltrate does not interfere with the immunoassay to determine testosterone (Table 3). Likewise, the efflux of sugar from the collector does not substantially affect the transfer of testosterone from the external liquid into the device. With the collector in the mouth, the external sucrose concentration is maintained at a low level owing to constant replenishment of saliva resulting from ongoing secretion and swallowing. This is different in the in vitro experiment, where the external volume is maintained constant at $10 \mathrm{ml}$ and the sucrose concentration increases with time. However, only a small difference was found between the recovery 1n in vitro studies (Fig. 4, ca. 85\%) and the recovery using the collector in the mouth (Fig. 5, ca. $87 \%$ ), which might just represent experimental variation.

Citric acid is a very potent stimulant of saliva secretion and has frequently been used to facilitate the collection of saliva. In this and parallel studies with the collector, some patients reported the beneficial effect of initially stimulating salivary flow in order to hydrate the device. However, if used as a component of the osmotically active substance in the collector, the acidic ultrafiltrate might interfere with accurate determinations in immunoassays, especially if large volumes of the filtrate are used in the assay procedure Low $\mathrm{pH}$ can disrupt antigen-antibody binding and is widely used to dissociate antigens from immobilized antibodies in affinity chromatography. The calculated high concentration of testosterone in samples containing a comparatively high concentration of citric acid might reflect low binding of radiolabeled tracer owing to the chaotropic effect of hydrogen ion (Table 4). This effect can be overcome with the use of an assay buffer that contains a higher concentration of phosphate to neutralize the hydrogen cons.

The potent effect of citric acid for salivary stimulation is now achieved by applying a small amount of the acid to the outside of the membrane. This initiates salivary flow at the beginning of the collection procedure and stimulation is thereafter contınued by turning around the hydrated device in the mouth (a similar effect to that achieved by chewing bubble gum). Citric acid is soon diluted and the interior of the collector attains neutral $\mathrm{pH}$.

'The high concentration of osmotically active substance in the ultrafiltrate necessitates the determination of the volume of water in the sample. At a density of $1.20 \mathrm{~g} \mathrm{ml}^{-1}$, about only two thirds of the volume pipetted for the immunoassay is water [19]. Therefore, the concentration determined in the ultrafiltrate needs to be multiplied hy a correction factor, $f$ ( $f=1.5$ at a density of $12 \mathrm{~g} \mathrm{ml}^{-1}$ ). The density of regular saliva is close to unity (1 002-1.012 $\mathrm{g} \mathrm{ml}^{-1}$ [35]) and does not changes after ultrafiltration through an Amicon filter (results not shown). 


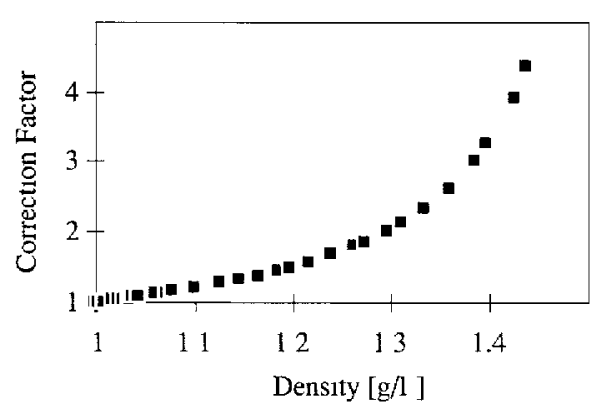

Fig. 7 Correlation between the density in the ultrafiltrate and the correction factor to account for the carbohydrate concentration follows a polynomal regression of the fourth order (calculated from [19])

The relationship between density and the correction factor is shown in Fig. 7. The polynomial regression follows the equation

$f=426.8-1495.8 x+1965 x^{2}-1146 x^{3}+250.8 x^{4}$ with a correlation factor of $r=0.999$ (e.g., insert the density, $x$, to obtain the correction factor, $f$, with which the obtained concentration of the sample will be multiplied).

A small change in density above ca. $1.3 \mathrm{~g} \mathrm{~m}^{-1}$ is accompanied by a larger change in the correctıon factor than at densitıes below $1.3 \mathrm{~g} \mathrm{ml}^{-1}$. This may affect the choice of the design of the collector. For example, if individual densities are not detcrmined but a predetermined time of collection with an average density is selected, the collector containing $1 \mathrm{~g}$ of sucrose has an advantage. The change in density with time is smaller with this design than with the collector containing $2 \mathrm{~g}$ of sucrose (Fig. 2) and about $3 \mathrm{ml}$ of ultrafiltrate accumulated over a period of 15 min with the collector containing $1 \mathrm{~g}$ of sucrose. This is a sufficient volume for the determination by $1 \mathrm{~m}$ munoassay or LC of most drugs and physiological markers in saliva. On the other hand, a larger volume of filtrate can be collected with the former device.

The described method for collecting an ultrafiltrate of saliva in situ for the determination of testosterone can be applied to a number of physiological markers, therapeutic drugs, and drugs of abuse. The method combines several advantages, as follows.

Simplicity of collection: the simplicity of col- lection of saliva compared with the collection of blood has been emphasized by many investigators. However, many individuals dislike salivating into a container even on a visit to their physician, although, they are usually prepared to provide urine. Therefore, it is not uncommon that patients experience a psychological reaction of "dry mouth" if asked to provide saliva. The collection of an ultrafiltrate with the osmotic sampling device 1 s unobtrusive and can be performed under almost any circumstances.

Stimulation of salivary flow: many patients during traditional collection of saliva produce mainly froth, which is cumbersome for processing in the laboratory. Therefore, gustatory or mechanical stimulants are often used. However, these can either interfere with the analytical method or, in the case of mechanical stimulants, they can non-specifically take up the drug of interest, or they can lead to lacerations and blood contamination. The soft, pliable collector used in this study stimulates salivary flow moderately and does not have any of the potential disadvantages of traditional collection methods.

Exclusion of blood contamınation: some physiological markers and drugs are bound to proteins in blood and only a small portion is "free" (unbound). In many instances, only the free circulating fraction of the molecule is biologically active and of diagnostic value. It is usually the free portion that enters the salivary gland. Small lacerations in the buccal cavity can cause contamination of saliva with blood and, therefore, introduce protein-bound molecules. This can lead to erratic diagnostic values which are assumed to reflect the free portion of the molecule. Protein-bound molecules are excluded with this method of sampling.

Prevention of binding to proteins: drugs can be bound to mucoproteins and cellular debris in saliva [36], leading to an underestimation of concentrations and to high variations between samples. Further, storage and handling of samples (e.g., centrifugation to remove particulate matter) in this instance might substantially affect the quantitative measurement. With the collection of an ultrafiltrate in situ, drugs secreted in salıva are exposed to protemacious matter only for a few seconds so that potential uptake is minimized. 
Prevention of metabolic degradation: drugs can be degraded in saliva either by the microflora in the mouth or by enzymes from saliva and gingival flutd. For example, increased metabolism has been reported for patients with chronic gingival inflammation [37] and with submandibular gland cancer tumors [38]. The possibility of active salivary metabolism of testosterone has also been suggested [39]. The semipermeable membrane in the collector excludes enzymes and particulate matter, therefore reducing the risk of metabolic conversion of steroids and other drugs.

Reduction of viscosity: saliva has an extremely high viscosity owing to a high content of glycoproteins and mucins, which makes processing in the laboratory difficult. Pipetting errors, especially for smaller volumes, can be substantial. Mucopolysaccharides are mainly secreted by the sublingual and the submandibular glands. Because salivary secretion from the parotid glands increases faster upon stimulation $[40,41]$, a varying concentration of mucopolysaccharides can contribute to changes in viscosity between collections and, therefore, can contribute to increased variations in measured drugs. Up to $86 \%$ of glycoproteins and mucins are excluded by semipermeable membranes [42], and therefore variations and interference by these molecules are reduced.

Sterile sampling: as the semipermeable membrane excludes microorganisms, the collected ultrafiltrate is sterile. If the collector is sterilized (e.g., by irradiation, which does not damage the membrane), a completely sterile sample can be obtamed. If the interior of the membrane is not kept sterile during manufacture, it can be expected that the growth of microorganisms will be reduced to some extent owing to the high remaining concentration of sucrose in the ultrafiltrate and the comparatively low initial number of microorganısms. A sterilized collector is of particular value if the samples are not refrigerated (e.g., in field studies). As enzymes are also excluded, most molecules are expected to be stable for extended periods of time without refrigeration.

These investigations were supported in part by a grant from the Whitaker Foundation and by the US Army Research Office. The authors thank
Drs. Richard H. Smith and Paul A. Cratg for critical discussions and Gudrun Schramm for expert technical support.

\section{REFERENCES}

1 M A Navarro, TJ Rodriguez, B. Arranz, M.R. Bonnin and N Serrallach, Fertıl Steril, 52 (1989) 128.

2 C.C. Shreh, S.C. Chang, C R. Tzeng, J.J Huang, W J Nir and C.Y. Hong, Andrologia, 19 (1987) 614

3 M A. Navarro, J.M. Gomez, C.M. Villabona and R Bonnin, Arch. Intern Med, 147 (1987) 1189

4 R. Galard, M Antolin, R Catalan, P Magana, S Schwartz and J M. Castellanos, Int J Androl , 10 (1987) 597

5 M A. Navarro, F Aguilo, C M Villabona, C Torrecilla and $\mathrm{R}$. Bonnun, $\mathrm{Br}$ J. Urol, 63 (1989) 306.

6 L. Boccon-Gibod, M.H. Laudat, D Guiban and A. Steg, Eur Urol , 15 (1988) 99

7 R. Knussmann, $\mathrm{K}$ Christiansen and C Couwenbergs, Arch Sex Behav, 15 (1986) 419

$8 \mathrm{~K}$. Christiansen and R Knussmann, Horm Behav., 21 (1987) 170 .

9 J M Dabbs Jr, RL Frady, TS. Carr and N.F. Besch, Psychosom Med, 49 (1987) 174

10 K. Ruutiainen, E. Sannikka, R Santtı, R Erkkola and H. Adlercreutz, J. Clin Endocrinol Metab., 64 (1987) 1015

11 M Luısı, M Gasper, D Silvestrı, G.P Bernını, E Pucci, R Sgrill, F. Franch and P.M. Kıcovic, J Steroid Biochem., 17 (1982) 581

$12 \mathrm{~J}$ Heresova, Z Pobisova, R Hampl and L. Starka. Exp Clın. F.ndocrinol., 88 (1986) 219

13 N J Cook, GF. Read, R.F Walker, B. Harns and D Riad-Fahmy, Eur J Appl Physiol, 55 (1986) 634

$14 \mathrm{~K}$ Christiansen, $\mathrm{R}$ Knussmann and $\mathrm{C}$. Couwenbergs, Horm Behav, 19 (1985) 426.

15 DH Baucom, PK Besch and S Callahan, J Pers. Soc Psychol, 48 (1985) 1218

16 J J Wellen, A G. Smals, J.C. Rıjken, P W Kloppenborg and T J Benraad, Clın, Endocrinol, 18 (1983) 51

$17 \mathrm{~W}$ Schramm, RH imith, P.A Cratg, S-H Paek and H -H Kuo, Clin. Chum, 36 (1990) 1488

18 W M. Hunter and F.C. Greenwood, Nature (London), 194 (1962) 495

19 R C Weast (Ed), CRC Handbook of Chemistry and Physics, Chemical Rubber Co, Cleveland, OH, 1974, p D-231

$20 \mathrm{~K}$ Howard, M Kane, A. Madden, J.P Gosling and P.F Fottrell, Clin Chem, 35 (1989) 2044

21 G Magrinı, G Chiodonı, F. Rey and J.P Felber, Horm Res., 23 (1986) 65

22 F S Khan-Dawood, J K Choe and Y Dawood, Am J Obstet. Gynecol , 148 (1984) 441

23 C. Wang, P.E Nieschlag and A. Paulsen. J. Clin. Endocrinol. Metab, 53 (1981) 1021 
24 R.F. Walker, D W. Wilson, G.F. Read and D Riad-Fahmy, Int J. Androl., 3 (1980) 105

25 B.L. Bammann, C.B Coulam and N.-S Jiang, Am J. Obstet Gynecol, 137 (1980) 293.

26 P M. Baxendale and V.H.T. Jasmes, in G F. Read, D. Ruad-Fahmy, R F Walker and K Griffiths (Eds), Specificity of Androgen Measurements in Saliva, Alpha Omega Publishing, Cardiff, 1982, p 228.

27 C. Selby, P.A. Lobb and W.J Jeffcoate, Clın. Endocrinol, 28 (1988) 19.

28 R F Vining and R.A McGinley, J Steroid Biochem., 27 (1987) 81

29 M. Piazza, A. Chirıannı, L Picciotto, V. Guadagnıno, R. Orlando and P T Cataldo, J. Am Med. Assoc., 261 (1989) 244

30 M Piazza, A Chinann, V. Guadagmino, L. Picciotto and R. Orlando, Boll. Soc. It B1ol Sper., 64 (1988) 467

31 V H.T James and P M. Baxendale, in G.F. Read, D RiadFahmy, R.F. Walker and K Griffths (Eds), Androgens in Salıva, Alpha Omega Publishıng, Cardiff, 1984, p 193.
32 A.D. Swift and F.J Tames, in G F Read, D Ruad-Fahmy, R.F Walker and K. Griffiths (Eds.), Salivary Testosterone in Male Adolescents, Alpha Omega Publishing, Cardiff, 1982 , p. 210

33 R McVie, L.S Levine and M I. New, Pediatr Res, 13 (1979) 755.

34 R F Walker, F.D. Riad and G F. Read, Clin Chem, 24 (1978) 1460

35 Wissenschaftliche Tabellen Gergy, Tellband Körperflüssigkeiten, CIBA-Geigy, Basle, 1977, p 112.

36 C K Svensson, M.N Woodruff and J G. Baxter, Clın. Pharmacokinet., 11 (1986) 450

37 T M El Attar, J. Steroid Biochem, 6 (1975) 1455

38 T M. El Attar, Stero1ds, 24 (1974) 519

39 W.M Pardridge, Clin. Endocrinol Metab., 15 (1986) 259

40 C Dawes and C.M. Wood, Arch Oral Biol, 18 (1973) 343

41 L.H Schneyer, J. Appl Physiol, 9 (1956) 79

42 T.E Daniels and E. Newbrun, Arch Oral Biol, 11 (1966) 1171. 